\title{
The Swedish Archaeological Society Celebrates its 70th Anniversary
}

In January 1947, a petition was sent to the head of the Swedish National Heritage Board by a number of leading figures in the archaeological community. The goal of the petition was to establish '[a] forum for assembly and discussions [...], which would serve as the natural meeting-point for Swedish archaeologists of very diverse orientations and leanings.' In May that same year, the Swedish Archaeological Society was inaugurated at a meeting in the Swedish History Museum. Today the Society is alive and well, celebrating its 70th anniversary this year, and to mark this occasion we wish to reflect upon the history of the Society as well as on its future. This text is based on the work of Nils Ringstedt who wrote a detailed history of the Society in the newsletter Gjallarhornet and on the website of the Society (www.arkeologiskasamfundet.se, in Swedish).

How did the need for a Society emerge? The general sentiment in the petition was that Swedish archaeology had diversified and there was a need to create a space where Scandinavian prehistorians, classical archaeologists, medieval scholars, osteologists, numismatic experts, orientalists and East-Asian specialists could meet and discuss methodology and findings. Swedish archaeologists were active in almost all parts of the world, the petition argued. The Royal Swedish Academy of Letters, History and Antiquities, which had previously been dominated by archaeologists and historians, had by the I940s branched out to include other scholars within the Humanities. The Society would, in this respect, serve as an interest organization where membership, very much as in the Academy, depended on having 'performed significant contributions to the respective scientific fields' within archaeology. The 
Swedish Antiquarian Society, which had existed since I869, had members from both the general public and from professional archaeology, but the Swedish Archaeological Society would cater to professionals exclusively. Its first chairman was the sinologist Professor Bernhard Karlgren (I889-I978), Director of the Museum of Far Eastern Antiquities in Stockholm. Since Karlgren, thirty-one chairpersons have left their mark on the Society.

Throughout its history, the Society has developed from an academic and male-dominated organization into an interest group that aims to cater to a diverse set of archaeologists, working in multiple specializations. The Swedish Archaeological Society has tried to follow the internal development of the profession, with varying results. More and more women have entered archaeology as researchers and fieldworkers, highlighting issues of inequality and professional self-imagery. However, despite an increasing number of female archaeologists, only four women have chaired the Society so far. Greta Arwidsson (I906-I998), professor of Scandinavian Archaeology at Stockholm College (later Stockholm University) became the first female chairperson in 1963. Arwidsson was also the first woman to rise to the rank of professor in archaeology in Sweden in 1956. In the late 1940s, Swedish archaeology was undergoing rapid change. A decade earlier, the national survey of ancient monuments had begun (it was not finished until 1993). Throughout the decades following the Second World War, more and more archaeologists became employed in infrastructural programmes and museum collections expanded rapidly. Theoretically and practically, some archaeologists approached the natural sciences, diversifying the field with new methods and specializations. Others moved towards what we today would call the heritage sector, working with public outreach and the mediation of cultural heritage. Today, the statutes state that the mission of the Society is to safeguard the interests of the archaeological community, to track and mediate new developments in archaeological knowledge production, and to take an active part in the cultural debate.

Today, the Society acts as an interest group for archaeologists who are employed in various fields, from university staff and researchers to contract archaeologists and employees of the Swedish Heritage Board and museums across the country. Unlike in the past, when membership was based on recommendation and nomination from existing board members, the Society is now an open organization where archaeologists can apply for membership. As part of its mission to safeguard the interest of the archaeological community, the Society is frequently employed to give expert opinions on new government legislation. In 2000 , the Society issued ethical guidelines for archaeological practice styled 
after the guidelines posted by the European Association of Archaeologists. Over the years it has organized debates and workshops on current affairs, and several of these workshops and panels have resulted in publications discussing the state of Swedish archaeology, both domestically and abroad. An example of this is the well-attended debate organized in 2005 in connection with the new permanent exhibition Forntider (Prehistories) at the Swedish History Museum. In 2008, the Society organized a large three-day conference at Lund University on the future of archaeology which was attended by a wide array of scholars debating archaeological thought and practice. Another example is the workshop Archaeologists without borders? held in $20 \mathrm{II}$, that featured leading scholars discussing issues of heritage politics, global migration and identity construction in the 2Ist century.

The journal that you are now reading, Current Swedish Archaeology, has been published by the Society since 1993 and it is a vital part of the Society's mission to communicate research and promote debate. In recent years, the Society has set aside money for organizations and private individuals to organize 'Archaeology cafés' where archaeologists and the public can meet and mingle in an informal setting. In an effort to expand the archaeological horizon beyond Sweden, the Society has organized trips to well-known heritage sites in Italy, China, Syria, Lebanon, Greece, Cyprus, Latvia and Lithuania. Social media has also become an important platform for the Society, and it has an active Facebook page that posts news relevant to anyone interested in archaeology. The newsletter Gjallarhornet, published since the I980s, is now digitally distributed to all members and gives up-to-date information on the Society's activities as well as news about current excavations and new books. The Society is in charge of a donation from Rosa and Victor Tengborg's Foundation and since 1976 it has granted a large number of stipends to young researchers, both Swedish and foreign. The Tengborg stipend, as well as smaller grants from the Society's Memorial Fund, are meant to encourage a new generation of students to pursue archaeology as a career.

Looking towards the future, we hope that the Society can continue to play a role in the archaeological community as a platform for debate and a resource for information. One of the biggest challenges is to create a bridge and a space for dialogue between the university and contract archaeology, an ongoing challenge. With a concern that some archaeologies and archaeologists are not represented, the Society aims to create more geographical as well as disciplinary variation. By organizing more workshops and conferences in the near future, it is hoped that the Society can create such a platform. Privatization of contract archaeology 
and increasing competition between actors in the heritage industry are other areas that the Society keeps a close eye on. The current situation has in recent years created a separation between museums and contract archaeology, where archaeology has lost its historical position within the museum sector.

With its 600 members, the Society is looking forward to following and influencing the changing role of archaeology and heritage management in the future. Here's to the next 70 years of Swedish archaeology!

The Board of the Swedish Archaeological Society 